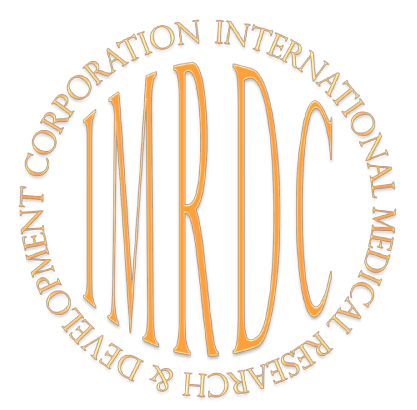

\title{
Dynamic Networks of Human Homeostatic Control in Norm (Part 1)
}

\author{
Alexander G. Kruglov, PhD, ScD; Georgiy Y. Gebel†, PhD, ScD; Valery N. Utkin; \\ Alexander Yu. Vasiliev, PhD, ScD; Veronoca A. Sherman \\ Central Research Institute of Radiation Diagnosis \\ Moscow, the Russian Federation
}

\begin{abstract}
The research has been undertaken to study the regional and common relationships between hemodynamic and metabolic parameters of human body functioning in individuals without clinical signs of pathology (in "norm"). Indicators of hemodynamics and metabolism were obtained by catheterization in a variety of areas: LV, RV, RA, CS, Ao, fixed SS, IJV, SVC, RHV, renal vena, and PT. Correlation and factor analyses were conducted for the study of: 1) the relationship between biochemical parameters in the blood stream, 2) the relationship between hemodynamic parameters, 3) relationship between the hemodynamic and biochemical parameters. Due to the nature of the correlation analysis, the significant $(\mathrm{p}<0.05)$ relation signs $(+, 0,-)$ without regard to their power were considered. The obtained results in the study of brain blood flow, heart, liver, lungs, kidneys suggested the existence of the primary homeostatic control of the factors determining rheological and thrombogenic properties of blood; the regulation of brain gas exchange and intracranial venous pressure by the minimum level of pressure in the cerebral outflow pathway-the pressure in RA; the regulating relationships between blood flow in CS with blood flow in RHV, RA, SS, and LV; and the existence of a synergistic complex of the relationships between the studied biochemical and hemodynamic characteristics that form the human homeostasis control matrix in norm. (Int J Biomed. 2016;6(2):101-105.).
\end{abstract}

Key Words: human homeostasis control matrix $\bullet$ hydrodynamic balance $\bullet$ hepatic venous outflow $\bullet$ coronary sinus

\section{Abbreviations}

Ao, aorta; $\mathbf{A V D O}_{2}$, arterio-venous oxygen content difference; BP, blood pressure; BSBR, basic set of biochemical regulations (constant during one cardiac cycle); CO, cardiac minute output; CS, coronary sinus; DP, diastolic pressure; Er, erythrocyte; F.d.p., final diastolic pressure; F-n, fibrinogen; IJV, internal jugular vein; IVC, inferior vena cava; LV, left ventricle; LA, left atrium; M, maximum pressure; MP, medium pressure; N, Norm; P-n, total protein; PI, plasma; PP, pulse pressure; PT, pulmonary trunk; RA, right atrium; RV, right ventricle; RHV, right hepatic vein; SS, sigmoid sinus; SinP, sigmoid sinus pressure; SVC, superior vena cava; SP, systolic pressure; SVP, hepatic sinusoidal pressure; SAH, stable arterial hypertension.

\section{Introduction}

The objective of the research was to identify the local and interregional qualitative relationships between indicators of blood chemistry; intraorgan and interregional hemodynamic correlations; the relationships between biochemical and hemodynamic parameters; the role of RA in the regulation of inter-organ relationships. For our research purposes, we opted

Corresponding author: Alexander G. Kruglov, PhD, ScD. Depute Director of Central Research Institute of Radiation Diagnosis, Moscow, the Russian Federation.E-mail: krag48@mail.ru for the hemodynamic pathway: $\mathrm{LV}-\mathrm{SS}-\mathrm{IJV}-\mathrm{SVC}-\mathrm{RA}$.

The results of these studies - as well as data of biochemical status, the levels of sinusoidal venous pressure of RHV and CS, obtained during catheterization in the group of healthy people (the norm) - have been repeatedly published previously..$^{[1-4]}$ We estimated the gradients of venous drainage from the liver; relationships between hemodynamic parameters and biochemical parameters of CS.

The aim of the study was also to supplement the matrix of interregional interrelations ${ }^{[5]}$ of studied parameters with data of the relationships between the hemodynamic parameters of RHV and CS. 


\section{Materials and Methods}

All of the research through which we received the discussed results was conducted in the same laboratory and with the help of the same methods in the supine position (in the perpendicular position to the vector of gravity when its influence in all parts of the venous system is equal). The data obtained by using the catheterization performed with a probe show BP levels and biochemical parameters at the outflow from the organ (brain and liver).

We performed the catheterization of LV, Ao, IJV, SVC, RHV, IVC, RA, RV, PT, and renal vein; ${ }^{[5-11]}$ during the procedure the pressure levels were recorded and blood samples were collected. The catheterization was performed by percutaneous puncture of the right femoral artery and the right femoral vein under local anesthesia, using the Seldinger technique. A vein dilator was used during the vein puncture. The catheter reached the aforesaid parts of the cardiovascular system. The arterial pressure values were recorded for the thoracic aorta. The studies were monitored by using radiography equipment.

The results for assessment were obtained from the studies conducted on apparently healthy people who were thoroughly examined in hospital before complex reconstructive maxillofacial surgery (these data have been represented in our early research papers). The total number of the examined people was 60 (48 men and 12 women). The age of 52 of those people ranged from 20 to 45 , and 8 people were over 45 years old. In 18 ( 13 males and 5 females aged from 21 to 42 years) people, out of necessity, catheterization of CS (for estimation of biochemical and hemodynamic parameters in 6 persons) and RHV (for biochemical parameters in 11 people and hemodynamic parameters in 14 people) was conducted. Statistical analysis was performed using the statistical software «Statistica 12.0».

\section{Results and Discussion}

When assessing the results, we took into consideration some principles of the general system theory, namely, regulation theory. Maintaining a constant internal environment when external conditions change is formulated as a homeostatic regulation. If there is a multitude of functional stability parameters, the self-regulating homeostatic system will find this multitude and restore the stability of the system, regardless of any changes in the environment.

The range of physiological changes, within which the optimum life activity for the present environment persists, is seen as normal. To define boundaries of the normal range we used the confidence interval boundaries set for each parameter and value; these boundaries define the range within which the probability of the relevant parameter value is $95 \%$. We have investigated the values of the following parameters: content levels of plasma electrolytes (K, Na) and red blood cells (Er); blood gases $\left(\mathrm{pO}_{2}, \mathrm{pCO}_{2}\right)$; acid-base composition $(\mathrm{pH}, \mathrm{SB})$; blood proteins: hemoglobin ( $\mathrm{Hb}), \mathrm{F}-\mathrm{n}$, total protein (P-n); and arterial venous difference $\left(\mathrm{AVDO}_{2}\right)$ in some segments.

We have investigated the following parameters of central and systemic hemodynamics (expressed in $\mathrm{mmHg}$ ): M, DP, PP, MP, F.d.p. for left and rhicht ventricles, and A/ X/ $\mathrm{V} / \mathrm{Y}$ waves for RA.

The correlation analysis was conducted to study the relationship between the biochemical characteristics of the blood flow and the hemodynamic values of the cerebral blood inflow and outflow in apparently healthy people and to compare them with the respective characteristics of the SAH group. ${ }^{[12]}$

The comparison of the sets of correlation relationships between biochemical and hemodinamic parameters revealed a drastic change in the entire set of relationships typical of norm, including loss of correlations with the end products of brain metabolism ( $\mathrm{pO} 2$, the $\mathrm{pCO} 2$, etc.) and between parameters of cerebral flow and rheology, which describe the general and plasma viscosity (Hb, F-n) in the cerebral outflow pathway. Normally, the hydrodynamic pressure in SS varies in accordance with changes in oncotic and gas pressure, as well as blood viscosity parameters. These connections are lost in $\mathrm{SAH}$.

The results obtained and processed by methods of mathematical statistics and presented $\mathrm{in}^{[4]}$ and a number of our works suggest that rheological properties of blood (its viscosity) can be seen as an initially regulated parameter of homeostasis. We assume, as proven, that the integrated hydrodynamic formation (SS-IJV-SVC-RA - is one of the cerebral gas exchange regulators, where the main regulator is the minimum pressure along the pathway of cerebral blood outflow - pressure in RA.

Earlier, we have discussed the results of our research, ${ }^{[3,12-18]}$ which allow us to review and analyze cardiac hemodynamics as a "single entity" consisting of functional units: 1) "atrial unit" - RA and LA; 2) "aortopulmonary unit" - bulb of the aorta and PT; 3) "three-chamber unit" of ventricles, consisting of a) " the left chamber" (LV) and b) "the richt chamber" (RV) with blood outflow from the chambers into "aorto-pulmonary unit", and c) "spongy" venous chamber with blood outflow from the myocardium (during the united systole) through CS and Thebesian veins into the "atrial unit." During "united systole" of "three-chamber unit" of ventricles, the following blood volumes are moved: 1) LV and RV stroke volume into the "aorto-pulmonary unit"; 2) stroke volume from the "spongy" venous chamber into the "atrial unit" (volumes of \#1 and \#2 constitute a united stroke volume of the "three-chamber unit"; and 3) blood inflow from SVC/IVC and pulmonary veins into the "atrial unit" during systolic/membrane blood suction and during the retraction of the tricuspid and mitral valves in the ventricular cavity during the blood expulsion from them. Thus, a united systole of "three-chamber unit" of ventricles is the basis for regulation: 1) the inflow (mobilization) of blood into the "atrial unit"; 2) systolic synchronization of hemodynamics in the "aortopulmonary" and "atrial" units; 3) intracardiac conditions of blood outflow from all chambers of the "three-chamber unit" of the ventricles through the fixed rings of CS, truncus pulmonalis, and bulb of the aorta. The volume of the blood moved by ventricular myocardium during this period is more than a united stroke volume by the amount of venous blood mobilized to the "atrial unit." 
$\mathrm{X}$-collapses in RA create a stable phase gradient of the venous drainage from the liver into RA. ${ }^{[2,19]}$ It remains positive (i.e., provides a constant outflow from RHV into RA) throughout the united systole of the "ventricular unit," when the other phase gradients are zero or negative. ${ }^{[2,19]}$ It was shown that there is a synchronization of this flow with the same phases of flow outflow from the brain, lungs, and kidneys. As manifestations of a single process (myocardial contractility), all the indicators of a period of united systole change conjugate. We believe that this is the basis of the systolic regulation of venous outflow from the organs (including the liver) into the "atrial unit."

A phase of the diastolic synchronization of intraorgan pressures, which takes place on the background of enddiastolic pressures in the ventricles, aorta, and pulmonary artery, occurs at open atrio-ventricular valves and the created united chambers: 1) "RV, RA, the veins of the great circle"; 2) "LV, LA, pulmonary veins." In this phase, there is a minimization of the differences between the levels and gradients of the pressures inside of the united chambers and between them. Our data [1] allow to consider CS not only as a vessel for venous blood flow from the myocardium, but also as a channel of intracardiac regulation of LV function by the level of booster pressure in RA, and by the level of pressure in the united chamber (RV-RA) in phase of diastolic synchronization.

During united systole of the "ventricular unit," an impulse of pulse wave reaches all segments of the arterial system until the closure of the aortic valve, in the period of maximum pressure of united hemodynamic chamber - (LVaorta). The spherical dissipative wave structure of pulse flow provides the most energy and information-rich processes of the aortic chamber, being one of the foundations of the urgent regulation, an adaptation. Thus, the heart moves not only the hemodynamic volumes in the vascular bed, but also generates the control-wave signals spreading to the exchange zones of organs. A general and regional vascular resistance with reduced vascular resistance in areas of increased metabolism (increased blood flow) is a mosaic information field for the source of the laminar arterial pressure (heart).

The obtained hemodynamic parameters of right HV, PT and CS allow us to group the extended summary matrix table (Table 1) of synergistic relationships for parameters of metabolism and hemodynamics in addition to the human homeostasis control matrix in norm published earlier. ${ }^{[5]}$

\section{Conclusion}

Our findings suggest that the dynamic processes of RA hemodynamics are a zone of unstable hydrodynamic balance within from 0 to $10 \mathrm{mmHg}$, having a number of fixed values (equal to pressure levels in pressure-bearing veins) synchronized with the phases of evolution of the cardiac cycle, which are the derived values from the dynamics of the cardiac cycle, as well as the threshold values for wave-control signals spreading to the exchange zone of organs, including the human heart.

The united systole of the "ventricular unit," in conjunction with the diastolic evolution of displacement of venous blood volumes of the right parts of heart, creating a wave pulses throughout the vascular system, provides to the heart the complete information volume of the common and regional mosaic vascular resistance, depending on the local metabolic activity during one cardiac cycle. We believe it is possible to assert that the generation of described wave processes by a united systole of the "ventricular unit" during one cardiac cycle in the arterial and venous flow creates a uniform pattern of control signals for the exchange areas of human organs, as well as information feedback signals for the "unified heart," affecting the structure of the next cardiac cycle.

\section{Competing interests}

The authors declare that they have no competing interests.

\section{References}

1. Gebel GYa, Kruglov AG, Utkin VN, Bagdatyev VE, Dasaev AN, Golostenova LM. Importance of the human coronary sinus in the norm (synchronization in the circulatory system). Reports of the 10th Conference on Space Biology and Aerospace Medicine. Moscow; June 7-10, 1994:56-57.

2. Gebel GYa, Kruglov AG, Utkin VN, Golostenova LM, Dasaev AN, Ignatov NG, Suvorov SG. Venous hemodynamics in human liver. Russian J Gastroenterol Hepatol Coloproctol. 1997;5(Suppl 4):139-41.

3. Gebel G Ya, Kruglov AG, Utkin VN, Golostenova LM, Dasaev AN, Ignatov NG, Suvorov SG. The assessment of the "ventricular block" function in health individuals. The 3th World Congress of Pediatric Cardiology and Cardiac Surgery. Canada, 2001:439.

4. Kruglov AG, Gebel GYa, Vasilyev AY. Impact of intraextracranial hemodynamics on cerebral ischemia by arterial hypertension (Part 1 and 2). Int J Biomed. 2012; 2(2): 89-101. 5. Kruglov AG, Vasilyev AY, Sherman VA. Human dynamic homeostasis control matrix in the norm with psychophysiological aspects. New York: IMRDC, 2016.

6. Gebel GYa, Dasaev AN, Pravetsky NB, Khilkin AM, Vyachkileva NK, Yuryev YuP, et al. The state of the parameters of hemodynamic and liver gas exchange in the association with the biochemical composition of arterial blood in patients with hypertension. Proceedings of the "Conference of the 4th Management of the Ministry of Health". Moscow; 1977:28-29. 7. Gebel GYa, Dasaev AN, Belichenko IA, Kruglov AG, Gudenko VV, Utkin VN. Intracranial venous pressure in the norm and arterial hypertension. Abstracts of the 7th Union Conference on Space and Aerospace Medicine. Kaluga,1982. 8. Utkin VN, Dasaev AN, Gebel GAYa, Kruglov AG, Lilloson AA, Golostenova LM. The venous circulation of the liver at the stable hypertensions (arterial hypertension and pulmonary hypertension) and in healthy individuals. Proceedings of the All-Union Congress of Neurosurgeons. Yaroslavl, 1990:19.

9. Gebel GYa, Utkin VN, Dasaev AN, Kruglov AG, Smirnov EP, Golostenova LM, et al. Gas exchange in the heart, kidneys and splanchnic organs in the norm. Proceedings of the Conference «Intensive Therapy in the Endo- and ExoToxicosis». Ekaterinburg, 1993:20-24. 
Table 1.

The extended summary matrix table of synergistic relationships for parameters of metabolism and hemodynamics

\begin{tabular}{|c|c|c|c|c|c|c|c|c|c|c|c|c|c|c|c|c|c|c|c|c|c|c|c|c|c|}
\hline & & & & 0 & & & & RA & & & $\mathbf{R}$ & & L & V & & & & & in $P$ & & & & BSB & & \\
\hline & & SP & DP & PP & $\mathrm{MP}$ & $\mathrm{A}$ & $X$ & V & $\mathrm{Y}$ & MP & FDP & MP & SP & PP & MVC & IVC & SP & DP & PP & MP & K er & $\mathrm{Ht}$ & F-n & P-n & $\mathrm{H}-\mathrm{b}$ \\
\hline \multirow{13}{*}{ Ao } & $\mathrm{K}$ pl & & & & & - & - & - & - & $X$ & $\mathrm{X}$ & $\mathrm{X}$ & $X$ & $X$ & $\mathrm{X}$ & $\mathrm{X}$ & + & & & & & & & & - \\
\hline & $\mathrm{K}$ er & & & & & & & & & $X$ & $\mathrm{X}$ & $\mathrm{X}$ & $X$ & $\mathrm{X}$ & $X$ & $X$ & - & - & & - & & - & & & \\
\hline & $\mathrm{Na} \mathrm{pl}$ & & & & & & & - & - & $X$ & X & $X$ & $X$ & $X$ & $X$ & X & + & + & & & - & - & - & + & \\
\hline & $\mathrm{Na}$ er & & & & & - & - & - & - & $X$ & $\mathrm{X}$ & $\mathrm{X}$ & $X$ & $\mathrm{X}$ & $\mathrm{X}$ & $X$ & - & & & & + & & & & \\
\hline & $\mathrm{pH}$ & & & & & & & + & + & $X$ & $X$ & $X$ & $X$ & $X$ & $X$ & $X$ & - & - & & - & & & + & - & + \\
\hline & $\mathrm{pCO}_{2}$ & & - & & - & - & & & - & $X$ & $\mathrm{X}$ & $X$ & $X$ & $X$ & $X$ & $X$ & & & & & & & & & \\
\hline & SB & & - & & - & & & & & $X$ & $X$ & $\mathrm{X}$ & $X$ & $\mathrm{X}$ & $X$ & $\mathrm{X}$ & - & - & & - & & & & & \\
\hline & $\mathrm{pO}_{2}$ & & & & + & & & & & $X$ & $\mathrm{X}$ & $X$ & $X$ & $X$ & $X$ & $X$ & + & + & & + & + & & - & + & \\
\hline & $\mathrm{HbO}_{2}$ & & & & & & + & & + & $X$ & $X$ & $X$ & $X$ & X & $X$ & $X$ & & & & & & & & - & \\
\hline & $\mathrm{Hb}$ & & & & & & & + & & $X$ & $\mathrm{X}$ & $X$ & $X$ & $\mathrm{X}$ & $X$ & $\mathrm{X}$ & - & - & & - & & + & + & - & \\
\hline & $\mathrm{Ht}$ & & & & & + & + & + & + & $X$ & $X$ & $X$ & $X$ & $X$ & $X$ & X & - & - & & - & & & + & + & + \\
\hline & F-n & + & + & & & - & + & & - & $X$ & $X$ & $\mathrm{X}$ & $X$ & $X$ & $X$ & $X$ & - & - & & - & & + & & + & + \\
\hline & P-n & & & & & & & & & $X$ & $X$ & $\mathrm{X}$ & $X$ & $\mathrm{X}$ & $X$ & $X$ & + & + & & + & & & + & & - \\
\hline \multirow{14}{*}{$\operatorname{Sin} P$} & $\mathrm{~K}$ pl & & & & & - & - & - & - & , & X & X & X & X & $X$ & X & - & - & & - & & & + & & \\
\hline & $\mathrm{K}$ er & & & & & & - & + & + & $X$ & X & $X$ & X & $\mathrm{X}$ & X & X & & & & & & & & & \\
\hline & $\mathrm{Na} \mathrm{pl}$ & & + & & + & & & - & - & $X$ & $X$ & $X$ & $X$ & X & $X$ & $X$ & + & + & & + & + & + & & + & \\
\hline & $\mathrm{Na}$ er & & & & & & & & - & $X$ & $\mathrm{X}$ & $\mathrm{X}$ & $\mathrm{X}$ & $\mathrm{X}$ & $X$ & $\mathrm{X}$ & & & & & + & & & & \\
\hline & $\mathrm{pH}$ & & & & & - & & + & + & $X$ & $\mathrm{X}$ & $X$ & $X$ & $X$ & $X$ & $X$ & - & - & & - & - & + & & & \\
\hline & $\mathrm{pCO}_{2}$ & & & & & & & & & $X$ & $\mathrm{X}$ & $\mathrm{X}$ & $\mathrm{X}$ & $\mathrm{X}$ & $X$ & $\mathrm{X}$ & & + & & & & & & & \\
\hline & SB & & & & & & & + & & $X$ & $X$ & $X$ & $X$ & $X$ & $X$ & $X$ & - & - & & - & & & + & & \\
\hline & $\mathrm{pO}_{2}$ & & & & & & - & - & - & $\mathrm{X}$ & $\mathrm{X}$ & $\mathrm{X}$ & $\mathrm{X}$ & $\mathrm{X}$ & $\mathrm{X}$ & $\mathrm{X}$ & & & & & + & & & & \\
\hline & $\mathrm{HbO}_{2}$ & & & & & - & - & - & - & $X$ & $X$ & $X$ & $X$ & $\mathrm{X}$ & $X$ & $X$ & & & & . & & & & - & \\
\hline & $\mathrm{Hb}$ & & & & & & - & & - & $X$ & $X$ & $\mathrm{X}$ & $X$ & $\mathrm{X}$ & $X$ & $\mathrm{X}$ & - & - & & - & & & & . & \\
\hline & $\mathrm{Ht}$ & & & & & & + & + & + & $\mathrm{X}$ & $\mathrm{X}$ & $\mathrm{X}$ & $X$ & $\mathrm{X}$ & $\mathrm{X}$ & $\mathrm{X}$ & & & & & & & & + & \\
\hline & F-n & & + & - & & - & - & + & - & $X$ & $X$ & $X$ & $X$ & $\mathrm{X}$ & $X$ & $\mathrm{X}$ & - & - & & - & & & & - & \\
\hline & P-n & & & & & & & & & $X$ & $\mathrm{X}$ & $X$ & $X$ & $\mathrm{X}$ & $X$ & $X$ & + & & & + & & & - & & \\
\hline & $\mathrm{ABDO}_{2}$ & $\mathrm{X}$ & $X$ & $X$ & $X$ & + & - & + & + & $X$ & $\mathrm{X}$ & $X$ & $X$ & $\mathrm{X}$ & $X$ & $X$ & & + & & + & - & & & + & + \\
\hline \multirow{4}{*}{$\operatorname{Sin} P$} & SP & & & & + & - & + & & & + & & + & - & - & - & & $X$ & $\mathrm{X}$ & $X$ & X & & & & & \\
\hline & DP & & + & & + & & + & & & + & & + & - & - & - & & $X$ & $\mathrm{x}$ & $X$ & $\mathrm{X}$ & & & & & \\
\hline & PP. & & - & & & & - & & & & + & & & & & & $X$ & $X$ & $X$ & $X$ & & & & & \\
\hline & MP & & & & + & & + & & + & + & - & + & - & - & - & - & $X$ & $X$ & $X$ & $X$ & & & & & \\
\hline \multirow{4}{*}{ SVP } & SP & & - & + & - & - & - & - & - & - & - & + & X & X & $X$ & $X$ & - & - & - & - & & & & & \\
\hline & DP & & - & + & - & - & - & - & - & - & - & + & $X$ & $X$ & $X$ & $X$ & - & - & - & - & & & & & \\
\hline & PP & & & & & & & - & - & & + & + & X & $\mathrm{X}$ & $X$ & $X$ & - & - & - & - & & & & & \\
\hline & MP & & - & + & - & - & - & - & - & - & - & + & $X$ & $X$ & $X$ & $X$ & - & - & - & - & & & & & \\
\hline \multirow{4}{*}{ PT } & SP & + & + & & + & + & + & + & + & + & + & & X & X & X & $X$ & + & + & & + & & & & & \\
\hline & DP & & + & & + & & & & & & + & & $X$ & $X$ & $X$ & $X$ & & & - & & & & & & \\
\hline & PP & + & & & + & + & & & & + & & & $X$ & $X$ & X & $X$ & + & + & + & + & & & & & \\
\hline & MP & + & + & & + & + & + & + & + & + & + & + & $X$ & $\mathrm{X}$ & $X$ & X & & + & - & & & & & & \\
\hline \multirow{4}{*}{ SC } & SP & + & + & - & + & + & + & + & + & + & + & - & $X$ & $\mathrm{X}$ & $X$ & $X$ & + & + & - & + & & & & & \\
\hline & DP & & + & - & + & + & + & + & + & + & + & - & $X$ & $X$ & $X$ & $X$ & - & - & + & - & & & & & \\
\hline & PP & & + & - & & & & & + & & & - & $X$ & $\mathrm{X}$ & $X$ & $X$ & + & + & - & + & & & & & \\
\hline & MP & + & + & - & + & + & + & + & + & + & + & - & $X$ & $X$ & $X$ & $X$ & - & - & + & - & & & & & \\
\hline
\end{tabular}


10. Gebel GYa, Utkin VN, Dasaev AN, Kruglov AG, Golostenova LM, Ignatov NG, et al. Pressure (general, gas and hemodynamic) in human heart vessels (coronary sinus, pulmonary artery, aortic bulb) in the norm. Proceedings of the simposium "Clinic, diagnosis and treatment in the Russian Federation». Moscow, 1993:25-29.

11. Gebel GYa, Golostenova LM, Dasaev AN, Utkin VN, Kruglov AG, Bagdatyev VE, et al. Blood composition of the coronary sinus in healthy people. Proceedings of the 7 th Russian Symposium «Ecological and Physiological Problems of Adaptation». Moscow, April 26-28, 1994:59-60.

12. Gebel GYa, Kruglov AG, Golostenova LM, Dasaev AN, Utkin VN, Bagdatjev VE, et al. About function of the "ventricular block" in human heart. Proceedings of the 2nd World congress on pediatric intensive care, Rotterdam,1996; 22(Suppl 2): 163 .

13. Gebel GYa, Kruglov AG, Golostenova LM, Dasaev AN, Utkin VN, Bagdatjev VE, et al. "Ventricular block" function in a human normal heart. Proceedings of the Annual European Congress of Respiratory Society. Stockholm, Sept. 7-11, 1996. 14. Gebel G Ya, Kruglov AG, Golostenova LM, Dasaev AN, Utkin VN, Bagdatjev VE, et al. The function of the "ventricular block" in human heart. Intensive care for the young. Acta Anaesthesiology Scandinavica, 1996.

15. Gebel GYa, Kruglov AG, Utkin VN, Golostenova LM,
Dasaev AN, Bagdatyev VE, et al. The analysis of heart activity as a whole. Proceedings of the 1st Congress of Heart Association of CIS countries. Moscow, 1997:151.

16. Gebel GYa, Kruglov AG, Utkin VN, Golostenova LM, Dasaev AN, Ignatov NG, Suvorov SG. The analysis of the function of the «ventricular block» of the heart. Proceedings of the 4th All-Russian Congress of Cardiovascular Surgeons. Moscow, 1998:274

17. Gebel GYa, Kruglov AG, Utkin VN, Golostenova LM, Dasaev AN, Ignatov NG, Suvorov SG. Evaluation of the function of the «ventricular block» in the human heart. Proceedings of the 1st All-Russian Conference "Preventive Cardiology". Moscow, 2000:258-259.

18. Gebel GYa, Kruglov AG, Utkin VN, Golostenova LM, Dasaev AN, Ignatov NG, Suvorov SG. Summary gas pressure $(\mathrm{pO} 2+\mathrm{pCO} 2)$ in blood of sinus coronarius, arteria pulmonalis and the aorta in healthy adult humans. Proceedings of the 10th International Congress on Cardiovascular Pharmacotherapy. Japan, Kioto, 2001; 15(1):394..

19. Gebel GYa, Kruglov AG, Utkin VN, Golostenova LM, Dasaev AN, Ignatov NG, Suvorov SG. Regulation of the venous outflow from the human liver in the norm. Proceedings of the 4th All-Russia Session of the Scientific Center of Cardiovascular Surgery named after A.N. Bakulev. Moscow, 2000:124. 